\title{
RECENT EVOLUTION OF MARKET RESEARCH AND PUBLIC OPINION POLLING BUSINESS IN THE EU COUNTRIES
}

\author{
Laura Cătălina Țimiraş \\ Vasile Alecsandri University of Bacau \\ timiras.laura@ub.ro
}

\begin{abstract}
The purpose of this paper is to highlight the evolution of the market research and public opinion polling business in the EU countries in recent years (after 2010). Using the Turnover or gross premiums written indicator, it was found that the analyzed business experienced an upward trend over the period 2010-2015, but not for all EU countries, some of them experiencing decreasing of the indicator. At the same time, parallel with the increase of the Turnover or gross premiums written at the level of the EU, there was a slight decrease of the number of enterprises and number of persons employed in the market research and the public polling activity, a decrease which was more pronounced at the level of the old EU Member States. The paper also seeks to highlight the link between the macroeconomic outcomes and market size of market research and public opinion polling across EU countries, noting the existence of a direct and strong relationship between Gross domestic product and Turnover or gross premiums Written both at EU-28 level and by categories of old and new member states. The analysis was based on official statistical data provided by Eurostat.
\end{abstract}

\section{Keywords}

market research and public opinion polling; turnover or gross premiums written; number of enterprises; gross domestic product; EU member states

\section{JEL Classification \\ M31, M39, C10}

The increased need for market research is undoubtedly the result of general economic development, increased competition, the dynamism of market phenomena that are often difficult or impossible to estimate, the diversification of the needs of increasingly demanding and sophisticated consumers etc., context in which organizations are forced to support themselves in the decision-making process on this kind of market information.

Worldwide, according to Statista (2017), global revenue of market research business was 44.35 billion U.S. Dollars in 2015, rising by over 40\% compared to 2010 (31.24 billion US dollars). In total, Europe has a significant share, so that in 2015 over $37 \%$ of the global revenue of market research business belonged to it. (Figure 1) 


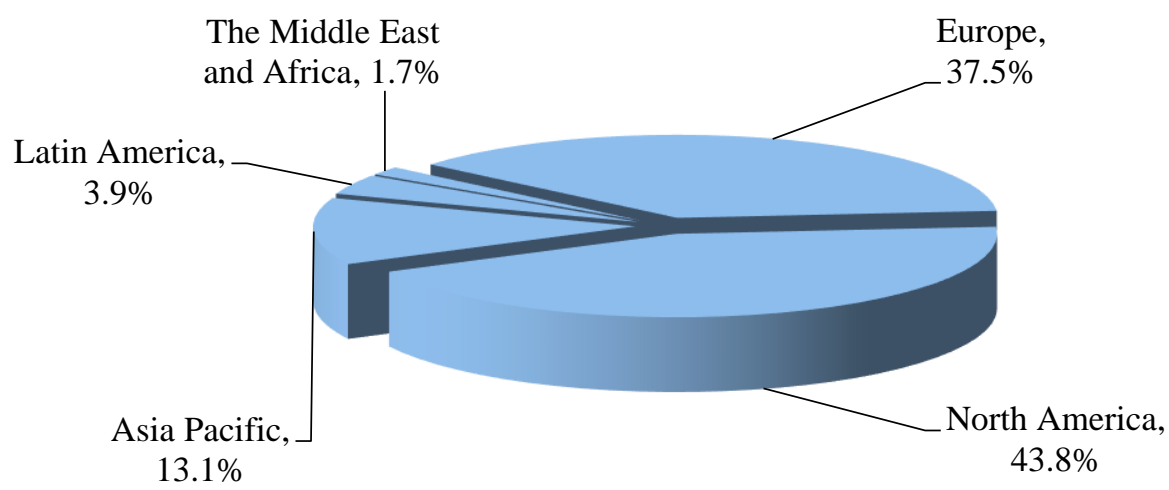

Figure 1. Structure of global revenue of market research business per World regions in 2015

Source: own computation after Statista, Inc. (2017)

Also among the top five largest market research companies in the world with 2015 global research revenue over 1 billion US Dollars, three belong to the EU. (Table 1).

Table 1. The largest operators in global market research activity in $\mathbf{2 0 1 5}$

\begin{tabular}{|l|c|}
\hline \multicolumn{1}{|c|}{ Companies } & Revenue (billion U.S. dollars) \\
\hline Nielsen Holdings N.V., United States & 6.17 \\
\hline Kantar, United Kingdom & 3.71 \\
\hline IMS Health Holdings INC. United States & 2.92 \\
\hline Ipsos SA, France & 1.98 \\
\hline Gfk SE, Germany & 1.71 \\
\hline \multicolumn{2}{|r}{ Source: Statista, Inc. (2017) } \\
\hline
\end{tabular}

\section{Methodological aspects}

The aim of this paper is to highlight the evolution of the market research and public opinion polling business in the EU countries after 2010 and also to analyze the link between the macroeconomic outcomes and market size of market research and public opinion polling across EU countries. The study is based on official statistical data, using, for their analysis, indicators for time series and for studying the links between variables.

\section{The size and market dynamics of market research and public opinion polling business at EU level}

The market size and dynamics of market research and public opinion polling business was assessed using the following indicators: Turnover or gross premiums written, as well as Number of enterprises, respectively, using the latest available official data provided by Eurostat.

Taking into account the Turnover or gross premiums written indicator, the market research and public opinion polling business at EU level reached 18.9 billions in 2015 (up with 5.1 percent compared to 2011). Almost $90 \%$ of the total turnover was made in the old EU member states (EU-15), while the new member states (Bulgaria, Czech Republic, Romania, Slovenia, Slovakia, Latvia, Lithuania, Croatia, Estonia) achieved 
just over $10 \%$ of this sum. Referring to the number of enterprises in the field of market research and public opinion polling business, in 2014 there were about 36.6 thousand businesses operating in the EU (down with 3.6\% compared to 2011), out of which about $74 \%$ belonged to the old EU states, and the number of persons employed in the field amounted to over 189 thousand persons in 2015 (with 1.1\% less than in 2011). Increasing Turnover or gross premiums written on the background of falling number of persons employed shows an increase in the efficiency of work in this field. In fact, this increase in efficiency was reflected only in the old EU member states (where number of people employed declined by $2.4 \%$ ), the indicator in the new EU member states rising. (Table 2 and Figure 2)

Table 2. The evolution of the market research and public opinion polling business at the EU level, respectively in the old and new member states, in terms of Turnover or gross premiums written, Number of enterprises and Number of persons employed

\begin{tabular}{|c|c|c|c|c|c|c|c|c|c|}
\hline \multirow[b]{2}{*}{$\begin{array}{l}\text { Country } \\
\text { groups }\end{array}$} & \multicolumn{3}{|c|}{$\begin{array}{l}\text { Turnover or gross } \\
\text { premiums written } \\
\text { (millions of } € \text {.) }\end{array}$} & \multicolumn{3}{|c|}{$\begin{array}{c}\text { Number of enterprises } \\
\text { (enterprises) }\end{array}$} & \multicolumn{3}{|c|}{$\begin{array}{c}\text { Number of persons } \\
\text { employed } \\
\text { (persons) }\end{array}$} \\
\hline & 2011 & 2015 & 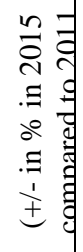 & 2011 & 2014 & 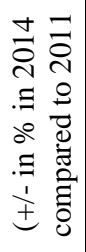 & 2011 & 2015 & 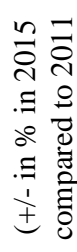 \\
\hline $\begin{array}{l}\text { The EU - } \\
15\end{array}$ & 16028.7 & 16883.0 & 5.3 & 28303 & 26934 & -4.8 & 160211 & 156427 & -2.4 \\
\hline $\begin{array}{l}\text { The new } \\
\text { member } \\
\text { states of the } \\
\text { EU }\end{array}$ & 1996.7 & 2063.6 & 3.4 & 9620 & 9641 & 0.2 & 31089 & 32709 & 5.2 \\
\hline $\begin{array}{l}\text { European } \\
\text { Union ( } 28 \\
\text { countries) }\end{array}$ & 18025.4 & 18946.6 & 5.1 & 37923 & 36575 & -3.6 & 191300 & 189136 & -1.1 \\
\hline
\end{tabular}

Source: own computation Eurostat (2017)

The results obtained from market research and public opinion polling business (Turnover or gross premiums written) and allocated resources (Number of persons employed) are not evenly distributed among the old and new EU members. Thus, according to figure no. 2 in 2015 , the old EU member states had $82.7 \%$ of total employees and $89.1 \%$ of total Turnover or gross premiums written, while at EU-15 level $17.3 \%$ of employees were employed and the share of total turnover was only $10.9 \%$. 


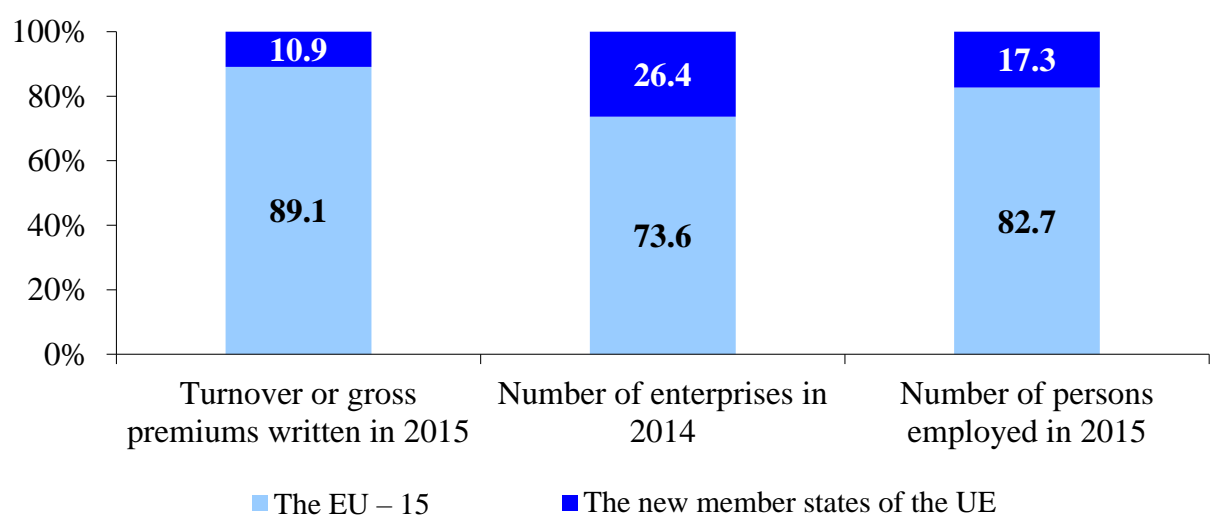

Figure 2. Structure of Turnover or gross premiums written, Number of enterprises and Number of persons employed in market research and public opinion polling business at old and new UE states level (\%)

Source: own computation from Eurostat (2017)

By EU countries, the largest market for research (market research and public opinion polling) in terms of Turnover or gross premiums written, belongs to the United Kingdom with a value of nearly EUR 5.5 billion, followed by other old Member States, such as: Germany, France, Netherlands, Italy, Spain (but with values below $50 \%$ of the level registered in the United Kingdom). At the level of the new EU member states, the size of the market is much lower, the largest market - the 8th in the EU-28 ranking, being owned by Poland (almost 0.6 billion Euros). (Figure 3)

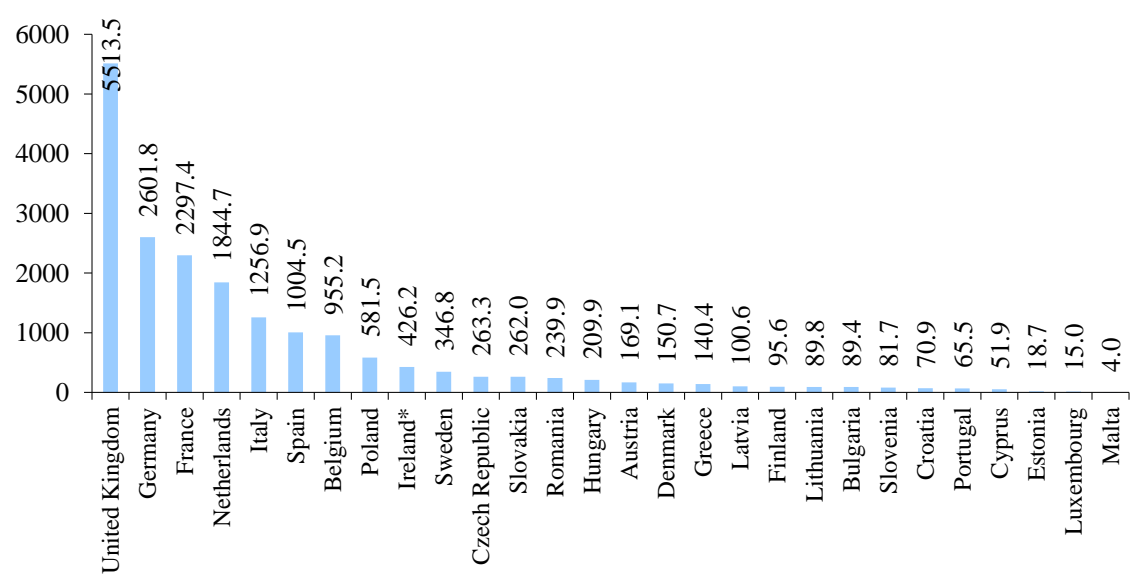

Figure 3. Turnover or gross premiums written made in market research and public opinion polling business by UE countries in 2015 (millions of $€$.) Source: Eurostat (2017) *2014 data

Over time, the evolution of the markets in the different EU countries was not the same. Thus, between 2010 and 2015, changes in the Turnover or gross premiums written indicator ranged very broad from increases of over $100 \%$ (in Ireland, where we are considering the 2010-2014 period), to decreases by more than $60 \%$ (for Malta). (Figure 4) 


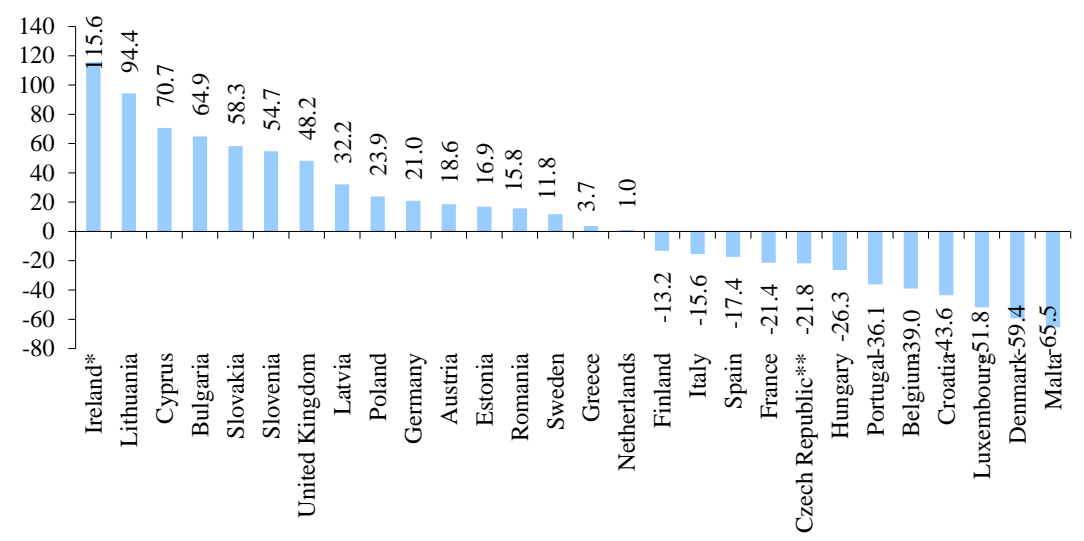

Figure 4. Percentage change in Turnover or gross premiums written in market research and polling business in EU-28 countries in 2015 compared to $2010(+/-$ in \% as compared to 2010)

Source: own computing from Eurostat (2017)

* 2014 compared to 2010

** 2015 compared to 2011

From the perspective of Number of enterprises in market research and public opinion polling business, the EU countries with the largest number of operators in 2014 are: Netherlands (with more than 6 thousand organizations), followed by: France, Italy, Spain, United Kingdom. (Figure 5)

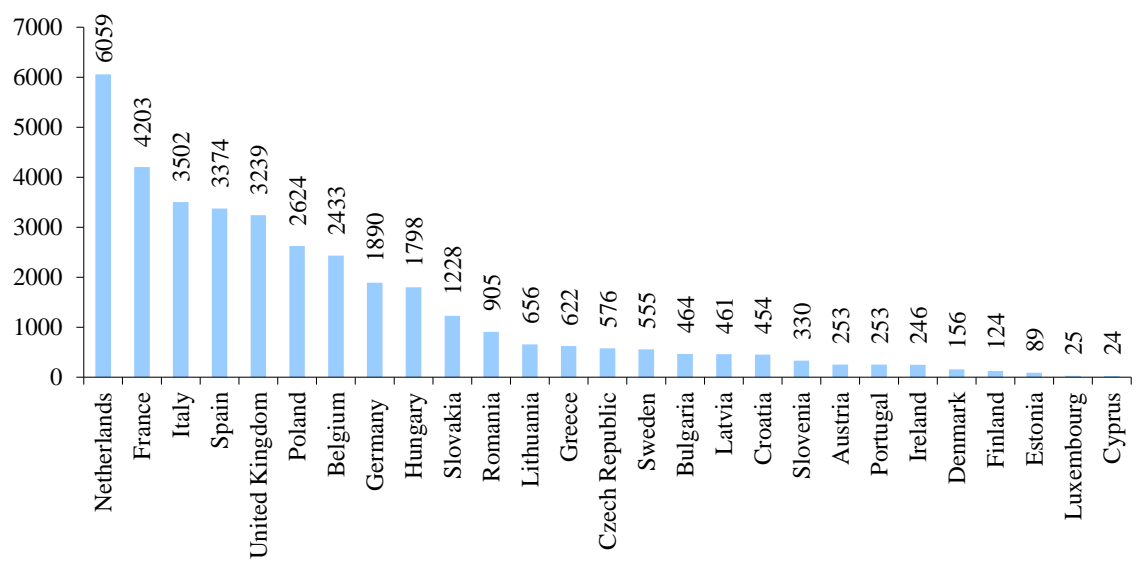

Figure 5. Number of enterprises in market research and public opinion polling business from EU-28 countries in 2014

Source: Eurostat (2017)

Note: no data for Malta

Like the Turnover or gross premiums written indicator, in the case of Number of enterprises in market research and public opinion polling business there have been different evolutions by country. A spectacular increase from this point of view was registered in Lithuania (more than 6 times in 2010-2014), with the rest of the countries registering increases ranging from $1.7 \%$ to $65.1 \%$. Still, in most EU countries there have been recorded decreases in the number of operators. (Figure 6) 


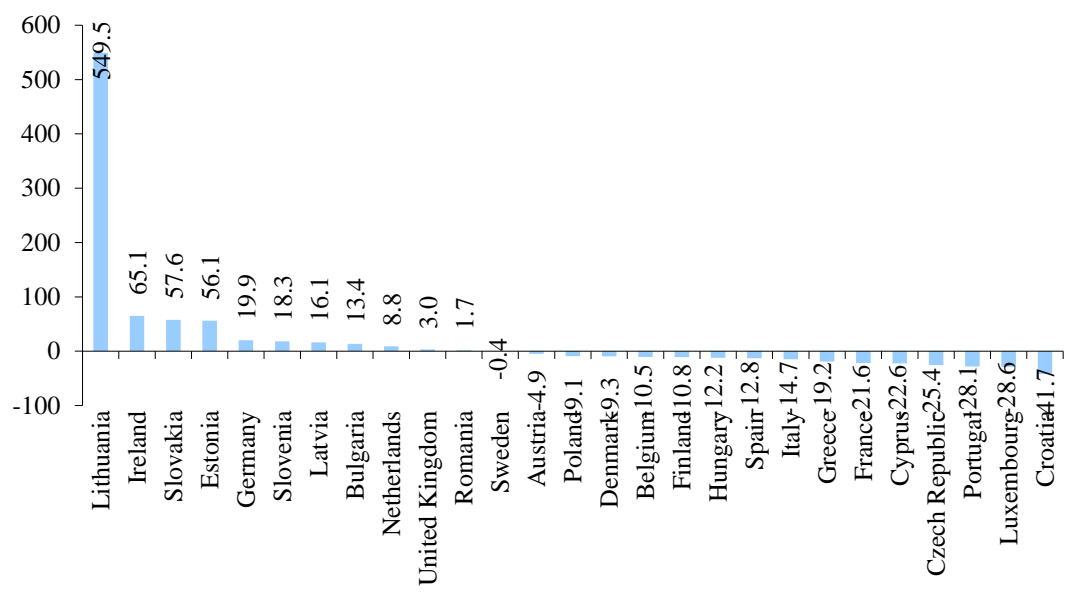

Figure 6. Percentage change in Number of enterprises in market research and polling business in EU-28 countries in 2014 compared to 2010 (\%)

Source: own computation from Eurostat (2017)

Note: no data for Malta

The link between the macroeconomic outcomes and market size of market research and public opinion polling business across EU countries in 2015 Studying the link between the Gross domestic product and the Turnover or gross premiums written in the market research and public opinion survey business in the 28 EU states, there is a strong link between the level of macroeconomic outcomes and the size of the analyzed market. Thus, according to figure no. 7 and table no. 3 it is observed that the bond is direct and strong, the correlation coefficient $r$ being of 0.871 .

Using the Fisher test to verify the significance of the determined link, it is found that this is significant for a significance level $\alpha$ of 0.001 . (Table 3)

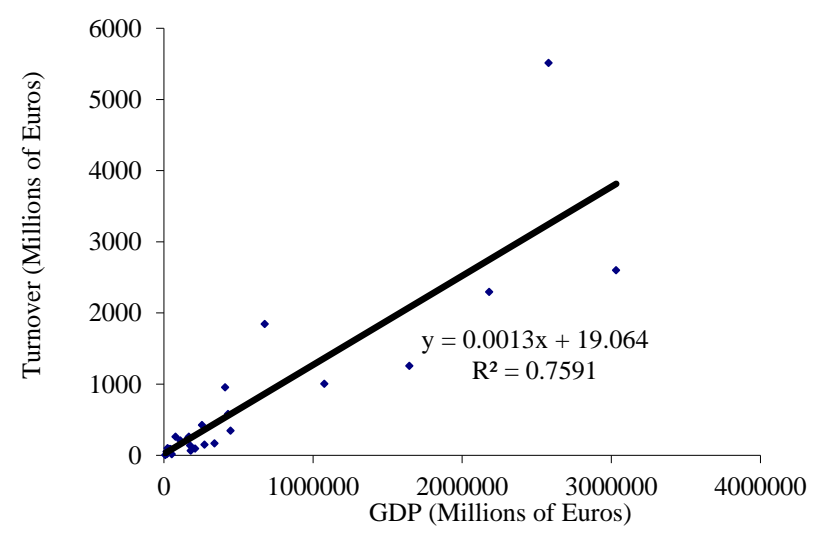

Figure 7. Link between Gross domestic product and Turnover or gross premium writing in Market Research and Public Polling business in EU-28 Countries in 2015

Source: own computation from Eurostat (2017)

Notă: for Ireland,it was used Turnover or gross premiums written for 2014.

Similarly, for the new EU members the evaluation of the link between Gross domestic product and the Turnover or gross premiums written in the activity of market research 
and public opinion polling, it was found that the direct nature of the relationship between the two variables is also verified, the intensity of the relationship being stronger for the new member states (the correlation coefficient $r$ calculated for the new EU member states has a value of 0.962 , while for the EU-15 it was 0.841). (Figure 8 and Table 3)

In this case, the determined relationships are significant for a significance level $\alpha$ of 0.001 , as evidenced by the Fisher test. (Table 3 )

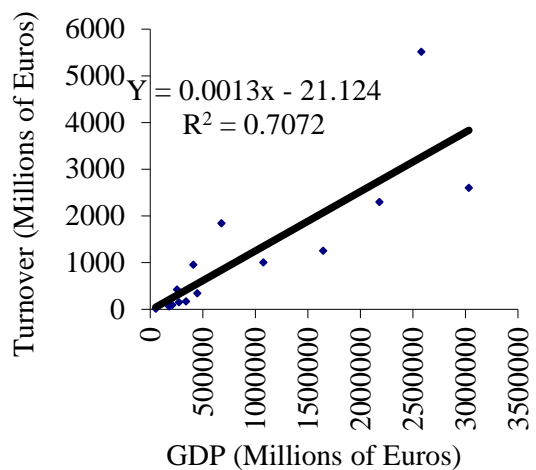

EU - 15

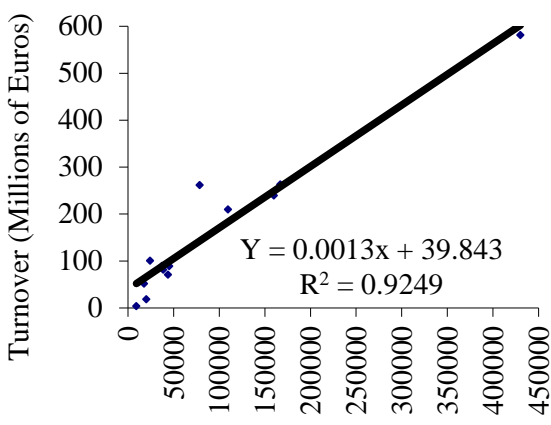

GDP (Millions of Euros)

New EU Member States

Figure 8. Relationship between Gross domestic product and Turnover or gross premiums written in Market Research and Public Polling Activity by Categories of Countries - Old and New EU Member States in 2015

Source: own computation from Eurostat (2017)

Notă: for Ireland, it was used Turnover or gross premiums written for 2014.

Table 3. Relationship between Gross domestic product and Turnover or gross Premiums Written in Market Research and Public Opinion Polling Business in EU Countries in 2015

\begin{tabular}{|c|c|c|c|c|c|c|c|c|}
\hline Countries & $\begin{array}{c}\text { Regressi } \\
\text { on } \\
\text { equation }\end{array}$ & \multicolumn{2}{|c|}{$\begin{array}{c}\text { Variation (sum of the } \\
\text { squares) }\end{array}$} & 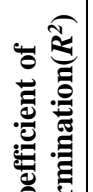 & 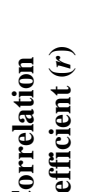 & 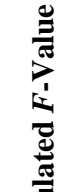 & 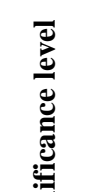 & 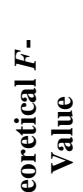 \\
\hline \multirow{3}{*}{$\begin{array}{c}\text { European } \\
\text { Union } \\
(\mathrm{EU}-28)\end{array}$} & \multirow{3}{*}{$\begin{array}{c}= \\
0.0013 x \\
+19.064\end{array}$} & Total & 37534591.4 & \multirow{3}{*}{75.9} & \multirow{3}{*}{0.871} & \multirow{3}{*}{81.9} & \multirow{3}{*}{0.001} & \multirow{3}{*}{13,74} \\
\hline & & Factorial & 28493243.8 & & & & & \\
\hline & & Residual & 9041347.6 & & & & & \\
\hline \multirow{3}{*}{ EU - 15} & \multirow{3}{*}{$\begin{array}{c}\mathrm{Y}= \\
0.0013 \mathrm{x} \\
-21.124 \\
\end{array}$} & Total & 30733769.4 & \multirow{3}{*}{70.7} & \multirow{3}{*}{0.841} & \multirow{3}{*}{31.4} & \multirow{3}{*}{0.001} & \multirow{3}{*}{17,81} \\
\hline & & Factorial & 21736283.0 & & & & & \\
\hline & & Residual & 8997486.5 & & & & & \\
\hline \multirow{3}{*}{$\begin{array}{c}\text { New EU } \\
\text { member } \\
\text { states }\end{array}$} & \multirow{3}{*}{$\begin{array}{c}Y= \\
0.0013 \mathrm{x} \\
+39.843\end{array}$} & Total & 291088.2 & \multirow{3}{*}{92.5} & \multirow{3}{*}{0.962} & \multirow{3}{*}{135.5} & \multirow{3}{*}{0.001} & \multirow{3}{*}{19,69} \\
\hline & & Factorial & 269233.2 & & & & & \\
\hline & & Residual & 21855.1 & & & & & \\
\hline
\end{tabular}

Notă: for Ireland, it was used Turnover or gross premiums written for 2014.

It is noted from the above table that the value of the regression coefficient has the same value at the level of the 3 equations determined (0.0013), which shows that both at the 
EU-28 and at the EU-15 levels, respectively the new members, on average, there is an increase of 1 billion Euro in Gross domestic product, related to an increase of 1.3 million Euro in the Turnover or gross premiums written in market research and public opinion polling business.

\section{Conclusions}

This paper highlights how the market for market research and public opinion polling across EU countries has evolved over the last years (2010-2015), as well as the link between the macroeconomic outcomes and the size of this market at the level of the analyzed countries.

For the market assessment, the indicators used were: Turnover or gross premiums written, Number of enterprises and Number of persons employed. The analysis was based on the latest available official data provided by Eurostat.

The market of organizations in market research activity and public opinion polling at the level of the EU registered an increase in the period 2010-2015 from the perspective of the Turnover or gross premiums written indicator, the upward trend reaching in 2015 almost 19 billion Euros; the old EU members hold over $89 \%$ of the total market. In the background of the increase in the Turnover or gross premiums written, the Number of enterprises and Number of persons employed registered a slight involution, which shows an increase in efficiency in this field.

Market size of market research and public polling organizations business at the level of the analyzed countries is closely related to the macroeconomic results recorded, with a direct and strong link between Gross domestic product and Turnover or gross premiums written both at EU-28 level, as well as by categories of old and new member states. The determined link shows that, on average, at the level of EU countries, an increase of 1 billion Euros of Gross Domestic Product generates an increase of 1.3 million Euros of the market research and public opinion polling activity.

\section{References}

Boier, R, Țimiraş, L.C. (2006), Cercetarea de marketing, Iaşi, Editura Performantica; Harja E., Țimiraş L.C. (2009), Metode statistice utilizate în cercetarea de marketing, Bacau, Editura Alma Mater

Sincich, T. (1989), Business Statistics by Example. Third Edition, Dellen Publishing Company

Ţimiraş, L. (2013), The Evolution of the Marketing Research Market on the Level of The European Union Countries, after 2000, Studies and Scientific Researches Economic Edition, No. 18, pp. 362-366, available at http://sceco.ub.ro/

Eurostat (2017), http://epp.eurostat.ec.europa.eu.

Statista Inc. (2017), https://www.statista.com 